\title{
Game Edukasi "River Guard" Berbasis Augmented Reality dengan Metode Dynamic Difficulty Adjustment
}

\author{
Wira Mahadhika Alphatora ${ }^{1}$, Pratama Wirya Atmaja ${ }^{2 *}$, Firza Prima Aditiawan ${ }^{3}$ \\ ${ }^{1,2,3}$ Informatika, Universitas Pembangunan Nasional "Veteran" Jawa Timur \\ 1434010130@student.upnjatim.ac.id \\ 3firzaprima.ifeupnjatim.ac.id \\ *Corresponding author email: pratama_wirya.fik@upnjatim.ac.id
}

\begin{abstract}
Abstrak- Banjir merupakan salah satu permasalahan yang kerap terjadi di Indonesia. Salah satu penyebab utama banjir adalah kebiasaan masyarakat membuang sampah di sungai. Masyarakat cenderung belum teredukasi mengenai dampak dari kebiasaan ini. Terdapat beberapa cara yang dapat dilakukan untuk mengatasi permasalahan ini, salah satunya dengan game edukasi. Game edukasi dipilih karena dengan edukasi yang menyenangkan akan menumbuhkan kemauan untuk belajar untuk anak - anak. Dengan pemanfaatan Augmented Reality, permainan menjadi menarik dan seru untuk dimainkan. Game edukasi ini bergenre strategy sehingga dapat merangsang polar pikir pengguna terhadap suatu masalah dan kejadian yang ada. Berdasarkan beberapa hal tersebut penulis ingin membuat sebuah permainan edukasi sampah yang berjalan dengan augmented reality menggunakan metode dynamic difficulty adjustment sebagai pengatur tingkat kesulitan pada permainan. Hasil uji kelayakan game River Guard berdasarkan kuesioner dari 20 responden menghasilkan perolehan sebesar $80,9 \%$. Berdasarkan perolehan hasil tersebut dapat disimpulkan bahwa game edukasi River Guard telah masuk dalam katergori layak.
\end{abstract}

Kata Kunci- game, sampah, augmented reality, dynamic difficulty adjustment, unity.

\section{PENDAhuluan}

Salah satu kebiasaan buruk orang Indonesia adalah membuang sampah di tempat sembarangan. Banyak kerugian akibat membuang sampah sembarangan salah satu contohnya adalah banjir. Banjir diakibatkan oleh air sungai yang meluap akibat sampah yang bertumpuk, selain itu juga menimbulkan banyak penyakit. Kebiasaan itu tentunya tidak lepas dari perilaku kebiasaan sehari-hari, masyarakat pada umumnya mempunyai kesadaran yang rendah dalam hal membuang sampah pada tempatnya. Maka perlu diadakan peningkatan pengetahuan dan kesadaran mengenai pentingnya tidak membuang sampah di sungai dalam masyarakat terutama pada anak-anak usia dini. Dengan demikian, terdapat beberapa cara yang dapat dilakukan untuk mengatasi permasalahan ini, salah satunya adalah game edukasi[1].

Dengan game berjenis edukasi bertujuan untuk memancing minat belajar anak, sehingga dengan perasaan senang diharapkan bisa lebih mudah untuk memahami pentingnya tidak membuang sampah sembarangan. Game edukasi ini dirancang untuk dapat berjalan pada perangkat yang sering digunakan oleh berbagai kalangan yaitu smartphone android. Seiring dengan perkembangan telepon pintar android atau smartphone android, konten multimedia juga turut berkembang pesat salah satunya adalah augmented reality yang banyak digunakan dalam industri game, hiburan maupun kedokteran[1].

Augmented Reality (AR) adalah teknologi yang menggabungkan benda maya dua dimensi maupun tiga dimensi ke dalam sebuah lingkungan nyata tiga dimensi lalu memproyeksikan benda-benda maya tersebut dalam waktu nyata. Dalam dunia pendidikan penggunaan teknologi Augmented Reality sendiri masih sedikit penggunaannya. Dengan pemanfaatan Augmented Reality, pembelajaran dapat disampaikan melalui representasi visual 3D dengan melibatkan interaksi user dalam augmented reality. Dengan menggabungkan gambar 2D konvensional yang akan digabungkan dengan teknologi 3D augmented reality yang dikemas dalam aplikasi berbasis Android yang dapat dimanfaatkan sebagai alat peraga sehingga dapat digunakan sebagai media pembelajaran yang lebih interaktif dan menarik bagi anak-anak[2].

Atas dasar itulah diharapkan dengan dibuatnya game edukasi berbasis augmented reality dapat menciptakan alat maupun metode pembelajaran baru dalam memahami pentingnya tidak membuang sampah di sungai yang lebih interaktif dan menarik dan dapat membantu dalam menyampaikan informasi tentang akibat membuang sampah di sungai..

\section{TINJAUAN PUSTAKA}

Cara paling mudah untuk memenuhi persyaratan format penulisan adalah dengan menggunakan dokumen ini sebagai template. Kemudian ketikkan teks Anda ke dalamnya

\section{A. Game}

Kata Game berasal dari bahasa inggris yang berarti permainan. Permainan adalah barang atau sesuatu yang dapat dimainkan dengan aturan tertentu sehingga menghasilkan menang atau kalah. Game atau permainan dapat menjadi suatu cara belajar yang dapat digunakan dalam menganalisa interaksi antara sejumlah pemain maupun perorangan yang menunjukkan strategi - strategi yang rasional [7].

B. Augmented Reality

Augmented Reality adalah teknologi yang menggabungkan benda maya dua dimensi dan ataupun tiga dimensi ke dalam sebuah lingkungan nyata tiga dimensi lalu memproyeksikan benda-benda maya tersebut dalam waktu nyata.Tidak seperti realitas maya yang sepenuhnya menggantikan kenyataan, namun Augmented Reality hanya menambahkan atau melengkapi kenyataan [4]. 


\section{Dynamic Difficulty Adjustment}

Dalam sebuah game dengan Dynamic Difficulty Adjustment, tingkat kesulitan yang dihadapi pemain berubahubah selama game berlangsung sesuai dengan tingkat kemampuan pemain. Apabila pemain memiliki tingkat kemampuan yang tinggi maka tingkat kesulitan game akan terus bertambah, dan akan menurun apabila tingkat kemampuan pemain rendah. Hal ini dapat dicapai dengan berbagai macam cara, terutama karena definisi sukses dapat berubah-ubah untuk tiap game. Keberadaan DDA mengimplikasikan keberadaan cara untuk memantau tingkat kesuksesan pemain dalam game. Hal ini dapat meliputi parameter seperti waktu yang diperlukan pemain untuk menyelesaikan objektif game, jumlah nyawa karakter yang hilang, dan lain sebagainya [5].

\section{Metodologi Penelitian}

Paragraf Pada penelitian ini, penulis membuat beberapa tahapan untuk memecahkan rumusan masalah dan mencapai tujuan dengan menggunakan metode pengembangan multimedia development life cycle (MDLC) versi LutherSutopo [1].

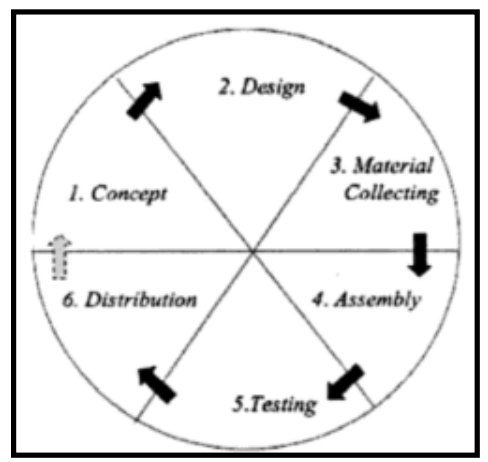

Gbr. 1 Tahapan Pengembangan MDLC ${ }^{[1]}$

\section{A. Concept (Pengonsepan)}

Pada tahap ini menentukan tujuan dan siapa pengguna program (identifikasi audiens). Pada tahap ini juga menentukan kebutuhan sistem aplikasi seperti konsep dari aplikasi dan gameplay yang dikembangkan [3]. Aplikasi permainan yang dikembangkan berjudul River Guard. Bertujuan untuk dapat membantu menyampaikan informasi pentingnya menjaga kebersihan lingkungan sungai. Aplikasi permainan berjalan pada platform android dengan genre strategy dan ditujukan pada masyarakat umum. Permainan ini dibuat dalam 4 level, memiliki map yang berbeda setiap levelnya. Pada setiap levelnya memiliki atura tertentu sehingga ada menang dan kalah. Deskripsi konsep permainan dapat dilihat pada tabel 1 .

TABEL I

DESKRIPSI KONSEP PERMAINAN

\begin{tabular}{|l|l|}
\hline Deskripsi & Keterangan \\
\hline Judul & River Guard \\
\hline Platform & Android \\
\hline Genre & Strategy \\
\hline Target & Umum \\
\hline
\end{tabular}

\begin{tabular}{|l|l|}
\hline Level Permainan & 4 Level \\
\hline Pemain & 1 pemain \\
\hline
\end{tabular}

\section{B. Design (Perancangan)}

Perancangan merupakan tahap dimana spesifikasi dibuat yang berisi beberapa aspek diantaranya arsitektur aplikasi, gaya, tampilan, dan kebutuhan meterial/bahan untuk aplikasi yang akan dibuat [3]. Pembuatan permainan edukasi River Guard berbasis Augmented Reality dengan metode dynamic difficulty adjustment dalam bentuk struktur navigasi. Struktur navigasi menggambarkan hubungan antar menu dalam bentuk bentuk hirarki. Struktur navigasi permainan edukasi River Guard berbasis Augmented Reality dengan metode dynamic difficulty adjustment dapat dilihat pada Gbr. 2.

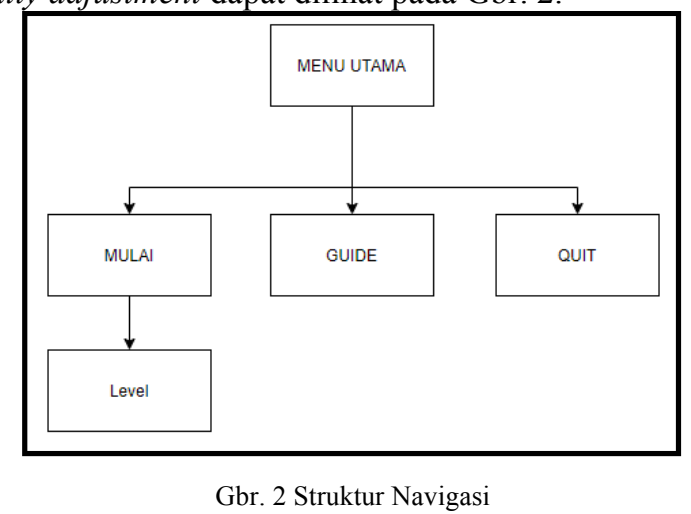

\section{Material Collecting (Pengumpulan Bahan)}

Material collecting adalah tahap pengumpulan bahan yang sesuai dengan kebutuhan yang dikerjakan antara lain gambar, clip art, foto, animasi, video, audio, dan lain-lain [1]. Berikut beberapa material yang dibutuhkan :

a. Object dalam permainan terbagi menjadi beberapa macam, yaitu tombol-tombol pada permainan, background dari main menu, sampah yang harus diambil, avatar pemain dan item-item lain yang muncul pada permainan.

b. Gambar yang dibutuhkan dalam permainan ini terbagi menjadi beberapa kegunaan, yaitu untuk tombol-tombol dari permainan dan background menu-menu yang lainnya.

c. Suara pada sebuah permainan digunakan pada saat terjadi interaksi dengan pemain seperti menekan tombol.

\section{Assembly (Pembuatan)}

Pada tahap ini dilakukan pembuatan dari permainan. Pembuatan disesuaikan dengan konsep dan desain yang telah dibuat sebelumnya[1]. Pembuatan objek - objek, implementasi augmented reality dan metode dynamic difficulty adjustment dilakukan menggunakan game engine Unity. Hasil dari pembuatan permainan kemudian di build untuk dapat berjalan di platform android menggunakan fitur build yang ada dalam Unity seperti Gbr. 3. Hasil build tersebut kemudian akan menjadi file ekstensi .apk . 


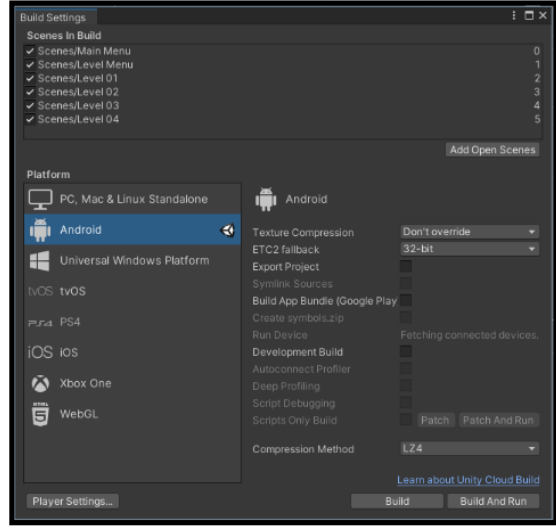

Gbr. 3 Proses build untuk platform Android

\section{E. Testing (Pengujian)}

Tahap testing (pengujian) dilakukan setelah menyelesaikan tahap pembuatan (assembly) dengan menjalankan aplikasi/program dan melihatnya apakah ada kesalahan atau tidak[3]. Pada tahap ini akan dilakukan pengujian terhadap permainan yang telah dibuat. Pengujian dilakukan dengan Pengujian blackbox dan kuesioner yang diberikan kepada peserta uji. Peserta uji berjumlah 20 orang dengan umur diatas 10 tahun. Pengujian dilakukan secara offline dan peserta uji memainkan permaina sebanyak 1 kalid engan waktu maksimal 20 menit.

\section{F. Distribusi (Pendistribusian)}

Pada tahap ini, aplikasi akan disimpan dalam suatu media penyimpanan[3]. Pendistribusian dilakukan untuk penyebaran dan penyampaian produk ke pengguna dari aplikasi yang telah selesai dibuat dan telah melalui pengujian. Pendistribusian file aplikasi permainan edukasi River Guard berbasis Augmented Reality dengan metode dynamic difficulty adjustment melalui link Google Drive.

\section{Pembahasan Dan Hasil}

Hasil dan pembahasan mengenai hasil dari perancangan yag ditetapkan sebelumnya. Pembahasan meliputi tampilan dan gamplay dari permainan edukasi River Guard berbasis Augmented Reality dengan metode dynamic difficulty adjustment serta hasil dari pengujian aplikasi.

\section{A. Tampilan Interface}

Pada bagian ini akan dibahas mengenai tampilan interface dari permainan. Interface yang dibahas meliputi tampilan setiap layout dari setiap pilihan menu dan tampilan dari setiap level permainan.

\section{a. Menu Utama}

Menu utama adalah tampilan pada saat permainan pertama kali terbuka. Pada menu utama terdapat menu untuk memainkan permainan.

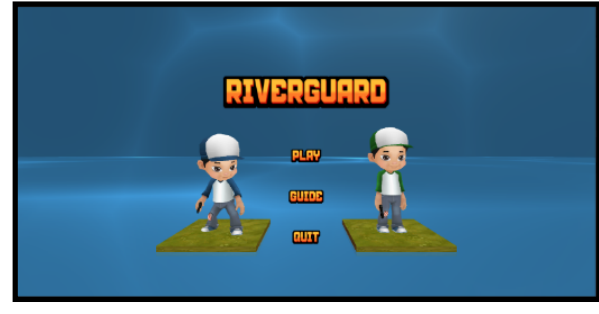

Gbr. 4 Menu Utama

Pada Gbr. 4 tampilan interface halaman menu utama permainan. Pada halaman ini terdapat judul permainan yaitu "RIVER GUARD". Terdapat 3 tombol menu yaitu play untuk memulai permainan atau memasuki halaman level permainan, tombol guide untuk membuka halaman cara bermain permainan, dan tombol quit untuk keluar dari permainan.

\section{b. Pause Menu}

Pada fitur pause ini digunakan untuk para pemain ketika ingin menjeda permainan untuk memudahkan pemain agar dapat melanjutkan permainannya dikala sedang ada kesibukan yang lain.

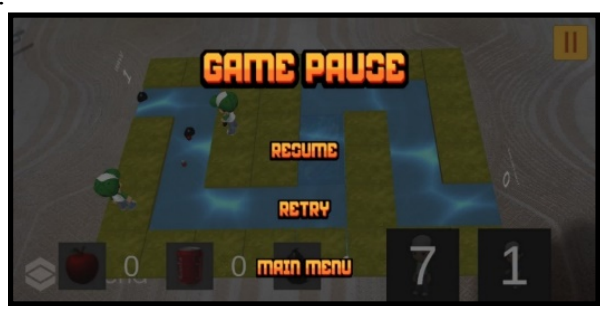

Gbr. 5 Menu Pause

Tampilan pause ini memiliki pilihan fitur resume yang digunakan untuk melanjutkan permainan, untuk fitur retry digunakan untuk mengulang permainan di level yang sama, untuk fitur main menu ini pengguna akan di alihkan kembali ke halaman utama dari game river guard ini.

\section{c. Level Selesai}

Pada setiap permainan pastinya juga ada tingkatan level yang membuat permainan tersebut akan seru untuk dimainkan, ketika berhasil menyelesaikan level yang mudah maka pengguna pun akan terpacu untuk menyelesaikan level berikutnya. Pada Gbr. 6 ini menampilkan gambar selesainya permainan pada level tertentu.

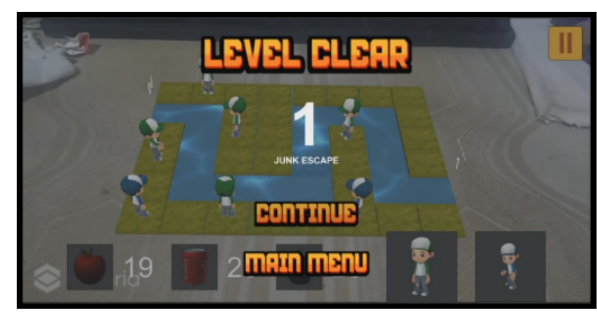

Gbr. 6 Menu Level Selesai

Pada Gbr. 6 ini tampilan level selesai, setiap menyelesaikan game di tiap levelnya, terdapat fitur tampilan nominal sampah yang lolos atau tidak. Kemudian fitur continue unutk melanjutkan ke level berikutnya. Jika pengguna ingin menyelesaikan permainan tersebut dapat 
menggunakan fitur main menu untuk kembali ke halaman utama game.

\section{d. Game Over}

Game over digunakan atau muncul kedalam permainan ketika sampah yang ada disungai lolos ke ujung sungai. Game dinyatakan gagal jika ada 10 sampah yang terlewati. Otomatis game akan memulai dari awal permainan di level tertentu.

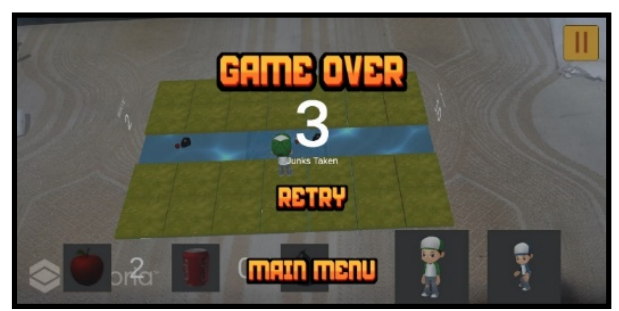

Gbr. 7 Menu Game Over

Pada Gbr. 7 berupa tampilan game over di game river guard, terdapat fitur nominal sampah yang sudah terambil selama game sebelumnya dimainkan. Kemudian fitur retry untuk memulai kembali permainan dari awal dengan level tertentu. Untuk fitur main menu sendiri digunakan untuk para pengguna ketika ingin kembali ke halaman utama.

\section{B. Augmented Reality}

Augmented reality digunakan untuk menampilkan area permainan pada game River Guard. Sebelum permainan dimulai pemain diharuskan meletakkan marker seperti pada Gbr. 8.

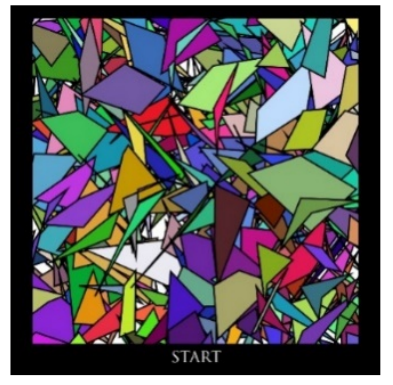

Gbr. 8 Marker

Setelah meletakkan marker, pemain mengarahkan kamera smartphone ke arah marker. Jika kamera berhasil membaca marker, area permainan akan muncul seperti pada Gbr. 9 dan pemain dapat memulai permainan.

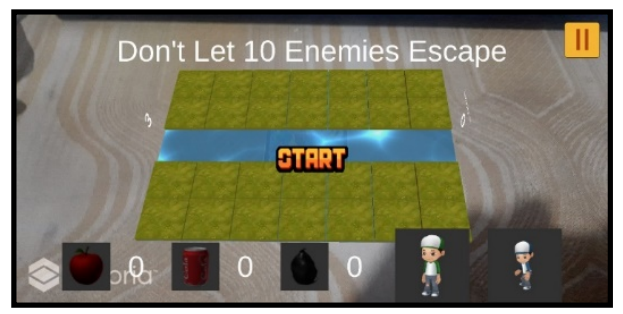

Gbr. 9 Marker Berhasil

Jika kamera gagal membaca marker seperti Gbr. 10 area permainan tidak akan muncul.

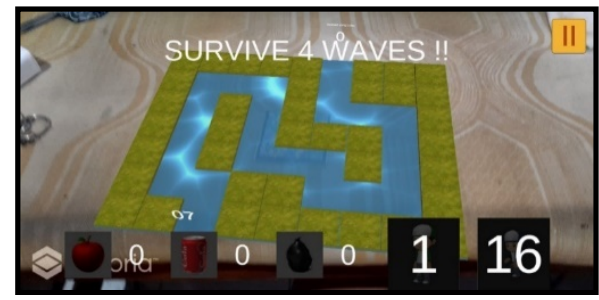

Gbr. 10 Marker Gagal

C. Dinamic Difficulty Adjustment

Penerapan Dynamic Difficulty Adjustment pada permainan dimulai dari wave ke 2 hingga player gagal mengambil sampah atau sampah lolos sampai goal. Pada wave pertama pemain akan bermain dengan tingkat kesulitan mudah. Tingkat kesulitan akan bertambah menyesuaikan tingkat keberhasilan pemain dalam mengambil sampah. Untuk menentukan tingkat kesulitan permainan, penulis menggunakan formula perhitungan. Berikut formula perhitungan untuk menentukan jumlah sampah :

$$
\mathrm{Z}=\left(W_{a} \times W_{k}\right)-\left(S x \frac{1}{2} W_{a}\right)
$$

$Z$ = Jumlah sampah Wave selanjutnya

$W_{a}=$ Wave awal

$W_{k}=$ Wave keberapa

$\mathrm{S}=$ Sampah yang lolos

\section{Hasil Pengujian}

Sebelum sebuah perangkat lunak diluncurkan ke publik, haruslah melalui tahap testing terlebih dahulu. Testing dilakukan untuk mengetahui apakah perangkat lunak yang dikembangkan terbebas dari error dan siap diluncurkan [6]. Pada tahap ini penulis melakukan dua pengujian yaitu pengujian alpha dengan blackbox dan pengujian kepada pemain dengan kuesioner.

a. Hasil Pengujian Black Box

Pengujian black box adalah pengujian alpha yang dilakukan oleh pihak internal yang dalam hal ini adalah penulis. Pengujian black box dilakukan untuk mengetahui apakah seluruh fungsional game RIVER GUARD ini telah bekerja dengan baik. Pengujian ini dilakukan pada device uji smartphone Samsung A7 (2018) yang berjalan pada OS Android 10. Fungsional yang diuji meliputi menu utama, menu guide, menu level, dan pengujian level. Hasil pengujian blackbox ditampilkan pada tabel 2 .

TABEL II

HASIL PENGUJIAN BLACK BOX

\begin{tabular}{|c|c|c|c|}
\hline KELAS UJI & SKENARIO & HASIL & KESIMPULAN \\
\hline \multirow{3}{*}{$\begin{array}{l}\text { MENU } \\
\text { UTAMA }\end{array}$} & $\begin{array}{l}\text { Klik Tombol } \\
\text { Start }\end{array}$ & $\begin{array}{l}\text { Menampilkan } \\
\text { level } \\
\text { permainan }\end{array}$ & Berhasil \\
\hline & $\begin{array}{l}\text { Klik Tombol } \\
\text { Guide }\end{array}$ & $\begin{array}{l}\text { Menampilkan } \\
\text { Guide Game }\end{array}$ & Berhasil \\
\hline & $\begin{array}{l}\text { Klik Tombol } \\
\text { Quit }\end{array}$ & $\begin{array}{l}\text { Keluar dari } \\
\text { Game }\end{array}$ & Berhasil \\
\hline MENU GUIDE & $\begin{array}{l}\text { Klik tombol } \\
\text { back }\end{array}$ & $\begin{array}{l}\text { Untuk } \\
\text { kembali } \\
\text { menu }\end{array}$ & Berhasil \\
\hline
\end{tabular}




\begin{tabular}{|l|l|l|l|}
\hline \multirow{5}{*}{} & & sebelumnya & \\
\cline { 2 - 4 } & $\begin{array}{l}\text { Klik tombol } \\
\text { next }\end{array}$ & $\begin{array}{l}\text { Untuk } \\
\text { melanjutan ke } \\
\text { menu } \\
\text { selanjutnya }\end{array}$ & Berhasil \\
\cline { 2 - 4 } & $\begin{array}{l}\text { Klik tombol } \\
\text { main menu }\end{array}$ & $\begin{array}{l}\text { Kembali ke } \\
\text { Menu Utama }\end{array}$ & Berhasil \\
\hline LEVEL & $\begin{array}{l}\text { Klik tombol } \\
\text { level 1 }\end{array}$ & $\begin{array}{l}\text { Menampilkan } \\
\text { game level 1 }\end{array}$ & Berhasil \\
\cline { 2 - 4 } & $\begin{array}{l}\text { Klik tombol } \\
\text { level 2 }\end{array}$ & $\begin{array}{l}\text { Menampilkan } \\
\text { game level 2 }\end{array}$ & Berhasil \\
\cline { 2 - 5 } & $\begin{array}{l}\text { Klik tombol } \\
\text { level 3 }\end{array}$ & $\begin{array}{l}\text { Menampilkan } \\
\text { game level 3 }\end{array}$ & Berhasil \\
\cline { 2 - 5 } & $\begin{array}{l}\text { Klik tombol } \\
\text { level 4 }\end{array}$ & $\begin{array}{l}\text { Menampilkan } \\
\text { game level 4 }\end{array}$ & Berhasil \\
\hline \multirow{5}{*}{$\begin{array}{l}\text { LEVEL } \\
\text { PERMAINAN }\end{array}$} & $\begin{array}{l}\text { Klik tombol } \\
\text { start }\end{array}$ & $\begin{array}{l}\text { Memulai } \\
\text { permainan }\end{array}$ & Berhasil \\
\cline { 2 - 5 } & $\begin{array}{l}\text { Klik tombol } \\
\text { pause }\end{array}$ & $\begin{array}{l}\text { Menampilkan } \\
\text { menu pause }\end{array}$ & Berhasil \\
\cline { 2 - 5 } & $\begin{array}{l}\text { Klik tombol } \\
\text { avatar hijau }\end{array}$ & $\begin{array}{l}\text { Untuk } \\
\text { memilih } \\
\text { avatar }\end{array}$ & Berhasil \\
\cline { 2 - 5 } & $\begin{array}{l}\text { Klik tombol } \\
\text { avatar biru }\end{array}$ & $\begin{array}{l}\text { Untuk } \\
\text { memilih } \\
\text { avatar }\end{array}$ & Berhasil \\
\cline { 2 - 4 } & $\begin{array}{l}\text { Klik area } \\
\text { permainan }\end{array}$ & $\begin{array}{l}\text { Untuk } \\
\text { meletakkan } \\
\text { avatar } \\
\text { dalam area }\end{array}$ & Berhasil \\
\hline
\end{tabular}

b. Hasil Kuesioner

Untuk mengukur penilaian pemain terhadap game River Guard dilakukan uji menggunakan skala likert. Pengujian ini menggunakan 20 soal pernyataan dalam kuesioner yang memiliki 5 faktor penilaian, yang dilakukan kepada 20 orang responden.

Pengujian dilakukan kepada pemain dengan rentang usia diatas 10 tahun. Pengujian dilakukan secara perorangan dimana penulis bertemu dengan responden dalam keadaan responden tidak sibuk dan dapat menjalankan tes tanpa tekanan,

Setiap responden memainkan game River Guard terlebih dahulu dan setelah bermain responden menjawab 20 soal kuesioner. Setelah 20 orang responden mengisi kuesioner didapatkan hasil perhitungan data yang ditampilkan pada Gbr. 11.

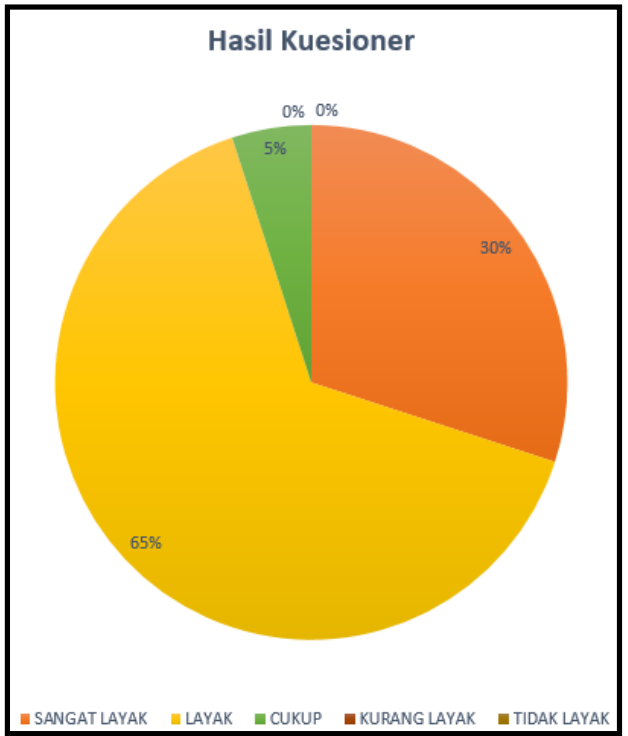

Gbr. 11 Hasil kuesioner responden terhadap game River Guard

\section{Kesimpulan}

Berdasarkan hasil dari pembahasan Game Edukasi "River Guard" berbasis augmented reality dengan metode dynamic difficulty adjustment ini dapat disimpulkan bahwa game edukasi "River Guard" menggunakan Unity dengan augmented reality dapat berjalan pada smartphone android. Permainan ini terdiri dari 4 level permainan yang berisi tentang menjaga kebersihan lingkungan sungai dengan mengambil sampah-sampah yang ada seperti sampah organik, kaleng dan plastik. Setiap levelnya menggunakan metode dynamic difficulty adjustment untuk menyesuaikan tingkat kesulitan permainan. Pengujian menggunakan metode Black Box menunjukkan bahwa permainan berfungsi dengan baik dam pengujian menggunakan skala likert menunjukkan hasil presentase sebesar $80.9 \%$ dengan katergori layak.

\section{REFERENSI}

[1] Jati, R. H. (2019). Rancang bangun permainan Platformer Edukasi Sampah dengan metode dynamic difficulty adjustment berbasis android. Surabaya: UPN Veteran Jawa Timur.

[2] Muntahanah, Toyib, R., \& Ansyori, M. (2017). PENERAPAN TEKNOLOGI AUGMENTED REALITY PADA KATALOG RUMAH BERBASIS ANDROID (STUDI KASUS PT. JASHANDO HAN SAPUTRA). Bengkulu: Universitas Muhammadiyah Bengkulu.

[3] Borman, R. I. \& Purwanti, Yogi (2019). Implementasi Multimedia Development Live Cycle pada Pengembangan Game Edukasi Pengenalan Bahaya Sampah pada Anak. Bengkulu: Universitas Muhammadiyah Bengkulu.

[4] Muntahanah, Toyib, R., \& Ansyori, M. (2017). PENERAPAN TEKNOLOGI AUGMENTED REALITY PADA KATALOG RUMAH BERBASIS ANDROID (STUDI KASUS PT. JASHANDO HAN SAPUTRA). Bengkulu: Universitas Muhammadiyah Bengkulu.

[5] Limantara, A. C. (2017). PENERAPAN DYNAMIC DIFFICULTY ADJUSTMENT PADA TYPING GAME WORDMASTER. Surabaya: Institut Teknologi Sepuluh Nopember.

[6] Cholifah, W. N., Yulianingsih, \& Sagita, S. M. (2018). PENGUJIAN BLACK BOX TESTING PADA APLIKASI ACTION \& STRATEGY BERBASIS ANDROID DENGAN TEKNOLOGI PHONEGAP. Jakarta Selatan: Universitas Indraprasta PGRI.

[7] Zikrillah, F. (2013). Aplikasi game 3D First Person Shooter (FPS) Survive From Death. Bandung: UNIKOM. 